\title{
Impact of Room Temperature on Chawki Stage and Its Effect on Later Stages of Double Hybrid, Bombyx mori L., Its Growth, Development and Cocoon Productivity
}

\author{
Arti Sharma ${ }^{1 *}$, Palvi Sharma1, Jyoti Thakur ${ }^{1}$, S. Murali², \\ Sardar Singh $^{2}$ and Nirmal Singh ${ }^{1}$ \\ ${ }^{1}$ Department of Sericulture, Poonch Campus, University of Jammu - 185101, India \\ ${ }^{2}$ Regional Sericultural Research Station, Central Silk Board, Miran Sahib, \\ Jammu - 181101, India \\ *Corresponding author
}

\section{A B S T R A C T}

\section{Keywords}

Larval duration, cocoon yield, shell ratio and Bombyx mori L.

Article Info

Accepted:

17 May 2018

Available Online:

10 June 2018
The effect of temperature plays a crucial role in the silkworm, Bombyx mori L., growth as well as cocoon quality and quantity. In this study, the effect of temperature during chawki rearing on later stages and its cocoon production was evaluated without maintaining any recommended practices of temperature and relative humidity during chawki rearing. The perusal of the data reveals that, the larval duration was observed as 28 days and 3 hours. It was observed that the second moult was the longest about 53 hours. Single cocoon weight was observed as $2.22 \mathrm{~g}$, single shell weight was $0.50 \mathrm{~g}$ and shell ratio percentage was $22 \%$ and yield obtained was $18.75 \mathrm{Kg}$ per 10, 000 larvae. This finding will help the sericulturists to rear silkworm even at room temperature during chawki stage without any standard procedures without much loss in the cocoon production.

\section{Highlights}

Double hybrid, Bombyx mori L. was evaluated in room temperature without providing standard conditions during chawki stage and it showed significant results. The study revealed that yield was recorded about $18.75 \mathrm{Kg}$ per 10000 larvae with shell ratio 22 per cent.

\section{Introduction}

Sericulture is an agro-based industry, involves rearing of silkworms for the production of raw silk. Bombyx mori L. is the most widely and intensively studied silkworm. Silk was first produced in China as early as Neolithic period. Today, China and India are the two main producers, with more than 97 per cent of the world's production. There are four types of commercially produced natural silk which is mulberry, tasar, eri and muga. The word "silk" generally refers to the silk produced by the mulberry silkworms as it is the most versatile and popular silk which contributes as much as 95 per cent of the total world's production. The other three commercially important silks fall under the category of non-mulberry silk, wild silk which contributes 5 per cent of the 
silk production. Silk, the most elegant textile fiber in the world with unparallel grandeur, natural sheen and drape is rightly christened as the "queen of textiles", for its royal look and feel. Silkworm is a larva of insects, which belongs to the order Lepidoptera experiencing complete metamorphosis, the mulberry silkworm, B. mori L. is a monophagous insect that feeds exclusively on mulberry foliage for its nutrition and produces the naturally proteinous silk. According to CSR\&TI, Mysore, silkworm rearing is an extensive month long exercise starting from egg stage and terminating in adult laying eggs and dying in their natural death. The growth of silkworm and their host plants are largely controlled by the surrounding climate. The temperature bears direct correlation with growth of silkworm as wide fluctuation of temperature is harmful to the development of silkworm (Muniraju et al., 2001). During this course, they pass through five larval instars intervened by four moults, cocoon and pupal stage. Whole life cycle spans through 45-55 days with 10-12 days of egg stage, 25-30 days of larval stage, 2-3 cocoon spinning days, 5-7 days as pupal days and 4-5 days as adult duration. The environmental conditions especially, temperature and relative humidity are vital in determining silkworm physiology as it is a cold-blooded organism (Benchamin and Jolly, 1986).

\section{Materials and Methods}

The investigation was carried out on double hybrid $\left(\mathrm{FC}_{1} \times \mathrm{FC}_{2}\right)$ received from NSSO, Bengaluru and experiment was conducted at RSRS, Miran Sahib, Jammu during spring, 2017 and the eggs were incubated for 9-12 days, maintained at $80-85$ per cent humidity and $24-25^{\circ} \mathrm{C}$ with $16 \mathrm{hrs}$ light till pin head stage, at this stage black-boxing was done to ensure maximum hatching on exposure to bright light. The hatched larvae were brushed separately and chawki rearing was conducted by room temperature and humidity without following any standard procedures. Chawki worms were fed with chawki leaves from the chawki garden in order to check the effect during later stages. After chawki, the worms were maintained by adopting recommended package of practice for maintaining temperature and relative humidity and larvae were fed four times a day with suitable quality leaves. Then silkworms were reared in three replications by counting 300 worms after second moult. The bed disinfectants were applied during molt and after the molt by recommended disinfectants.

\section{Schedule of feeding}

Chopped mulberry leaves were fed to the chawki worms and whole leaf feeding was followed for late age worms. The worms were fed four times a day at 6 a.m., 11 a.m., 4 p.m. and 9 p.m.

\section{Mulberry garden}

For rearing $\mathrm{S}$ - 146 mulberry variety grown in loamy soil with spacing of $3 \times 3 \mathrm{ft}$ plantation was used for the experiment.

\section{Observations recorded}

\section{Hatching (\%)}

After about one hour of hatching of layings, the percentage was worked out by using formula

$$
\text { Hatching }(\%)=\frac{\text { Number of eggs hatched }}{\text { Total number of eggs }}
$$

\section{Larval duration}

The time taken by the silkworm larvae from hatching to spinning was taken as larval duration and expressed in days. 


\section{Effective rate of rearing by Number}

Number of cocoon obtained from a total of 300 numbers of larvae reared in 3 replications were counted and converted proportionately for 10000 larvae.

\section{Effective rate of rearing by weight $(\mathrm{Kg})$}

Numbers of cocoon obtained from a total number of 300 larvae reared in 3 replications were weighed using an electronic digital balance and converted for proportionately 10000 larvae.

\section{Pupation rate (\%)}

After harvesting, the healthy cocoons were sorted out by removing melted, double and infected cocoons, and pupation rate was calculated by using the formula and expressed as percentage.

Number of good or healthy cocoons per $\mathrm{Kg}$ Pupation rate $(\%)=$----------------- x 100

Actual number of cocoons per $\mathrm{Kg}$

\section{Fifth instar mature larval weight}

In each replication ten worms were weighed individually and average of the ten worms were calculated to get the accurate single mature larval weight.

\section{Single cocoon weight}

The cocoons were harvested on sixth day after spinning. In each replication ten cocoons at random were weighed. Individual cocoon weight was taken for 10 cocoons and average was calculated to complete the mean cocoon weight.

\section{Single shell weight}

In each replication, ten cocoons were cut, pupae and cast skin were separated and the cocoon shell weight was recorded and average was calculated to get the mean shell weight.

\section{Shell ratio}

The cocoon shell ratio was calculated by using the following formula:

Shell weight (g) of Cocoon

Shell ratio $(\%)=------------100$

Cocoon weight $(\mathrm{g})$

\section{Results and Discussion}

Eight economic traits of data pertaining to evaluation viz., hatching percentage, larval weight (g), larval duration (days and hours), pupation rate $(\%)$, yield per 10,000 larvae by weight and number, single cocoon weight $(\mathrm{g})$, single shell weight (g) and shell ratio (\%) were presented in Table 1. The perusal of the data reveals that the hatching percentage was recorded from 93.50 to 95.70 whereas larval weight was recorded from 44.00 to $46.00 \mathrm{~g}$ whereas larval duration was recorded from 6 $\mathrm{D} 18 \mathrm{~h}$ to $6 \mathrm{D} 22 \mathrm{~h}$, whereas pupation rate was recorded from 93.30 to 95.30 per cent, whereas yield per 10,000 larvae by number and weight was recorded from 7200 to 8970 and 16.56 to $20.11 \mathrm{Kg}$ respectively. Whereas single cocoon weight was recorded from 2.18 to 2.27 , single shell weight was recorded from 0.47 to 0.55 with shell ratio ranging from 21.26 to 24.22 per cent.

Seven post cocoon parameters were evaluated $v i z$. , average filament length $(\mathrm{m})$, average nonbreakable filament length $(\mathrm{m})$, denier, defective cocoon percentage, renditta on good cocoons; reelability percentage and raw silk percentage of the three replications were presented in Table 2. The perusal of the data revealed that the average filament length was recorded from 1018 to 1026 whereas average non-breakable filament length was recorded from 1018 to 1026, whereas denier was recorded from 2.50 to 2.58 , the defective 
cocoon percentage from 6.30 to 6.38 , the renditta on good cocoons from 2.57 to 2.65, reelability percentage from 81.92 to 82.00 and raw silk percentage from 37.78 to 37.86 . There are ample literature stating that good quality cocoons are produced within a temperature range of $22-27^{\circ} \mathrm{C}$ and above these levels makes the cocoon quality poorer (Krishnaswami et al., 1973).

Silkworms were reared at room temperature up to chawki stage without any recommended temperature and humidity. During the last days of first instar the temperature and humidity ranges between $21-15^{\circ} \mathrm{C}$ and $81-53$ per cent respectively. The moulting period of first instar was normal i.e., 24 hours. In the second instar, the temperature and humidity ranges between $20-15^{\circ} \mathrm{C}$ and $81-53$ per cent respectively Table 3 . The decline in temperature is due to heavy rainfall up to two days. As a result of that the larval duration of second instar was five days which was extended up to one day as compared to worms reared in optimum conditions. The moulting period was also prolonged and that was about 53 hours. The normal duration of second moult is 18-20 hours where as in case of low temperature it was extended up to 33-35 hours. It was not observed in the history of sericulture till date.

By providing room temperature during the chawki the following changes has been recorded:

The larval duration of the chawki worms was prolonged i.e., 11 days and 10 hours.

The leaf consumption was more up to $3.5 \mathrm{Kg}$.

The moulting period was prolonged.

The size of chawki worms was comparatively small and weight was lower than the normal worms.

Table.1 Economic parameters of double hybrid reared during spring, 2017

\begin{tabular}{|c|c|c|c|c|c|c|c|c|c|}
\hline \multirow[t]{2}{*}{ Replication } & \multirow[t]{2}{*}{ H \% } & \multirow[t]{2}{*}{$\begin{array}{l}\mathbf{L W} \\
(\mathrm{g})\end{array}$} & \multirow[t]{2}{*}{$\begin{array}{c}\text { LD } \\
5^{\text {th }} \text { instar }\end{array}$} & \multirow[t]{2}{*}{$\begin{array}{l}\text { PR } \\
(\%)\end{array}$} & \multicolumn{2}{|c|}{$\begin{array}{c}\text { Yield per } 10,000 \\
\text { larvae }\end{array}$} & \multirow[t]{2}{*}{ SCW (g.) } & \multirow[t]{2}{*}{$\begin{array}{l}\text { SSW } \\
\text { (g.) }\end{array}$} & \multirow[t]{2}{*}{$\begin{array}{l}\text { SR } \\
(\%)\end{array}$} \\
\hline & & & & & No. & Wt. (Kg) & & & \\
\hline$\overline{\mathbf{R}_{1}}$ & 95.70 & 45 & $6: 22$ & 93.5 & 7200 & 16.56 & 2.21 & 0.47 & 21.26 \\
\hline $\mathbf{R}_{2}$ & 94.50 & 44 & $6: 22$ & 95.3 & 8432 & 19.58 & 2.18 & 0.48 & 22.01 \\
\hline $\mathbf{R}_{\mathbf{3}}$ & 93.50 & 46 & $6: 18$ & 93.3 & 8970 & 20.11 & 2.27 & 0.55 & 24.22 \\
\hline Mean & 94.56 & 45 & $6: 20$ & 94.0 & 8200 & 18.75 & 2.22 & 0.50 & 22.50 \\
\hline $\begin{array}{l}\text { SD } \\
\end{array}$ & 1.10 & 1.00 & 0.02 & 1.10 & 907.39 & 1.92 & 0.05 & 0.04 & 1.54 \\
\hline
\end{tabular}

Note: $D$-days, $h$ - hours, H-hatching, LW-Larval weight, LD-Larval duration, PR - Pupation rate, SCW-Single cocoon weight, SSW-Single shell weight, SR-shell ratio

Table.2 Post cocoon parameters of double hybrid reared during spring, 2017

\begin{tabular}{|c|c|c|c|c|c|c|c|}
\hline Replication & $\begin{array}{c}\text { Average } \\
\text { filament } \\
\text { length }(\mathbf{m})\end{array}$ & $\begin{array}{c}\text { Average non- } \\
\text { breakable filament } \\
\text { length(m) }\end{array}$ & Denier & $\begin{array}{c}\text { Defective } \\
\text { cocoon }(\boldsymbol{\%})\end{array}$ & Renditta & $\begin{array}{c}\text { Reelability } \\
(\%)\end{array}$ & $\begin{array}{c}\text { Raw } \\
\text { silk } \\
(\%)\end{array}$ \\
\hline $\mathbf{R}_{1}$ & 1026 & 1026 & 2.58 & 6.38 & 2.65 & 82.00 & 37.86 \\
\hline $\mathbf{R}_{2}$ & 1018 & 1018 & 2.50 & 6.30 & 2.57 & 81.92 & 37.78 \\
\hline $\mathbf{R}_{3}$ & 1022 & 1022 & 2.54 & 6.34 & 2.61 & 81.96 & 37.82 \\
\hline Mean & $\mathbf{1 0 2 2}$ & $\mathbf{1 0 2 2}$ & $\mathbf{2 . 5 4}$ & $\mathbf{6 . 3 4}$ & $\mathbf{2 . 6 1}$ & $\mathbf{8 1 . 9 6}$ & $\mathbf{3 7 . 8 2}$ \\
\hline SD & $\mathbf{4 . 0 0}$ & $\mathbf{4 . 0 0}$ & $\mathbf{0 . 0 4}$ & $\mathbf{0 . 0 4}$ & $\mathbf{0 . 0 4}$ & $\mathbf{0 . 0 4}$ & $\mathbf{0 . 0 4}$ \\
\hline
\end{tabular}


Table.3 Showing average meteorological data during spring rearing (2017)

\begin{tabular}{|l|l|l|l|l|l|l|l|l|}
\hline $\begin{array}{c}\text { Sl. } \\
\text { No. }\end{array}$ & \multicolumn{1}{|c|}{ Stage } & \multicolumn{1}{|c|}{ From } & $\begin{array}{c}\text { Dry. } \\
\text { Tem. }\end{array}$ & $\begin{array}{c}\text { Wet } \\
\text { Tem. }\end{array}$ & $\begin{array}{c}\text { Relative } \\
\text { humidity }\end{array}$ & $\begin{array}{c}\text { Range } \\
\text { Tem. }\end{array}$ & $\begin{array}{c}\text { Range } \\
\text { Humidity }\end{array}$ \\
\hline $\mathbf{1}$ & Incubation & 19.2 .17 & 2.3 .17 & 25 & 20 & 85 & $24-25$ & $83-85$ \\
\hline $\mathbf{2}$ & I instar & 2.3 .17 & 7.3 .17 & 20 & 18 & 69 & $15-21$ & $53-81$ \\
\hline $\mathbf{3}$ & II instar & 7.3 .17 & 13.3 .17 & 18 & 15 & 72 & $15-20$ & $53-81$ \\
\hline $\mathbf{4}$ & III instar & 13.3 .17 & 18.3 .17 & 23 & 18 & 56 & $15-27$ & $47-78$ \\
\hline $\mathbf{5}$ & IV instar & 18.3 .17 & 23.3 .17 & 24 & 19 & 57 & $17-26$ & $47-68$ \\
\hline $\mathbf{6}$ & V instar & 23.3 .17 & 30.3 .17 & 23 & 21 & 77 & $18-25$ & $47-95$ \\
\hline $\mathbf{7}$ & Mounting & 30.3 .17 & 6.4 .17 & 24 & 22 & 65 & $20-25$ & $60-70$ \\
\hline
\end{tabular}

The above mention changes arise when the temperature and humidity decreased during chawki rearing. The optimum temperature for chawki rearing is $27-29^{\circ} \mathrm{C}$ and humidity 85 90 per cent, below that condition the physiology of silkworm is affected. The environmental factors like temperature, humidity, light and air have great influence on growth and development of silkworm. These factors directly or indirectly control the physiological activities of silkworm larvae (Tazima 1978). Hence it is necessary to provide most favourable climatic conditions suited to the silkworms at different stages. Higher and lower temperature badly affects the physiology of silkworm.

Many reports investigated temperature or climatic effect on silkworm rearing for its growth and development. The effect of temperature higher than $30^{\circ} \mathrm{C}$ on silkworm larvae was reported earlier by Shirota (1992) and Tazima and Ohnuma (1995) while attempting to synthesise high temperature resistant silkworm races confirmed the genetical nature of thermo-tolerance by selection based on pupation rate of silkworms reared under high temperature conditions in fifth instar. Keeping these in view compatible bivoltine hybrids for rearing throughout the year were developed by utilizing Japanese thermo-tolerant hybrids as breeding resource material (Datta et al., 1997; Datta et al., 2000, Datta et al., 2001; Suresh Kumar et al., 2002, 2006: Dandin et al., 2006) and suggested that any study involving cocoon traits is a trend setter to provide basis to formulate appropriate selection policies for required environments. While studying the performance of robust and productive hybrids under two temperature conditions Suresh Kumar et al., (1999) and Datta et al., (2001) indicated that the deleterious effect of high temperature was more pronounced in productive hybrids than the robust hybrids.

The data obtained from experiment trial was concluded that by prevailing environmental conditions play a vital role in the rearing of silkworms in order to harvest good quality \& quantity of cocoons. The experiment observation shows that if the temperature and humidity is not maintained at the farmer level during chawki stage, the temperature lower than recommended can also give good crop production. Room temperatures can also give good results if proper hygienic conditions and quality leaf feeding are maintained during rearing.

\section{Acknowledgements}

The authors wish to thank the authorities of Regional Sericultural Research Station, CSB, Miran Sahib, Jammu - 181101, J and K. India, for their encouragement to undertake this work. The authors are also thankful to Dr. Sardar Singh, Scientist-D, for his assistance in conducting effective work and close monitoring during the study. We 
acknowledge all technical staff who assisted their help in rearing.

\section{References}

Ananthanarayan S. K., 2012. Silkworm rearing. Published by Biotech Books Delhi1110035.

Benchamin, K.V. and Jolly, M.S., 1986. Principles of silkworm rearing, Proc. of Sem. On problems and prospects of sericulture. S. Mahalingam (Ed), Vellore, India. 63-106.

Dandin, S. B., Suresh Kumar, N., Basvaraja, H. K., Mal Reddy, N., Kalpana, G. V., Joge, P. G., Nataraju, B., Balavenkatasubbaiah, M. And Nanje Gowda, B., 2006. Development of new bivoltine silkworm hybrid, Chamaraja (CSR50 x CSR51) of Bombyx mori L. for tropics. Indian J. Seric., 45: 2129.

Datta, R. K., Basavaraja, H. K., Suresh Kumar, N., Kishor Kumar, C. M. And Nirmal Kumar, S., 1997. Evolution of robust hybrids of bivoltine silkworm, Bombyx mori L. for tropics, XVIIth Congress of the International Sericulture Commission, Brazil, 22- $26^{\text {th }}$ April.

Datta, R. K., Suresh Kumar, N., Basavaraja, H. K. And Mal Reddy, N., 2000. "CSR18 x CSR19"- A robust bivoltine hybrid for rearing throughout the year. Abstr. Seminar on sericulture technology, an appraisal, Central Sericultural Research and Training Institute, Mysore, India, June 6-7, 2000 p.19.

Datta, R. K., Suresh Kumar, N., Basavaraja, H. K., Kishor Kumar, C. M. And Mal Reddy, N., 2001. "CSR18 x CSR19"- A robust bivoltine hybrid suitable for all season rearing in the tropics. Indian Silk, 39: 5-7.
Krishanaswami, S., Narasimhanna, M. N., Surayanarayana, S. K. and Kumararaj, S. 1973. "Manual on sericulture" Vol 2. Silkworm rearing UN Food and Agriculture Organisation, Rome, 54-88.

Muniraju, E. B., Sekharappa M., Raghuraman. R. (2001). Production silkworm, Bombyx mori L., under different rearing temperature. Indian Journal of Sericulture, 40: 15-20.

Shirota, T., 1992. Selection of healthy silkworm strain through high temperature rearing of fifth instar larvae. Reports of the Silk Science Research Institute, 40: 33-40.

Suresh Kumar, N., Basavaraja, H. K., Joge, P. G., Mal Reddy, N., Kalpana, G. V. And Dandin, S. B., 2006. Development of a new robust bivoltine hybrid (CSR46 x CSR47) of Bombyx mori L. for the tropics. Indian J. Seric., 45; 21-29.

Suresh Kumar, N., Basavaraja, H. K., Kishor Kumar, C. M., Mal Reddy, N. and Datta, R. K., 2002. On the breeding of "CSR $18 x$ CSR19"- A robust bivoltine hybrid of silkworm, Bombyx mori L. for the tropics. Int. J. Indust. Entomol, 5: 155-162.

Suresh Kumar, N., Kishor Kumar, C. M., Basavaraja, H. K., Mal Reddy, N., Ramesh Babu, M. and Datta, R. K., 1999. Comparative performance of robust and productive bivoltine hybrids of Bombyx mori L. under high temperature conditions. Sericologia, 39: 567-571.

Tazima, Y. and Ohnuma, A., 1995. Preliminary experiments on the breeding procedure for synthesizing a high temperature resistant commercial strain of the silkworm, Bombyx mori L. Silk. Sci. Res. Inst. Japan, 43: 1-16.

Tazima, Y., 1978. Silkworm egg. Scientific brochure (pub.) Central Silk Board, Bangalore, pp.24-25.

\section{How to cite this article:}

Arti Sharma, Palvi Sharma, Jyoti Thakur, S. Murali, Sardar Singh and Nirmal Singh. 2018. Impact of Room Temperature on Chawki Stage and Its Effect on Later Stages of Double Hybrid, Bombyx mori L., Its Growth, Development and Cocoon Productivity. Int.J.Curr.Microbiol.App.Sci. 7(06): 1521-1526. doi: https://doi.org/10.20546/ijcmas.2018.706.180 